\title{
Associations between subclinical hypocalcemia and postparturient diseases in dairy cows
}

\author{
E. M. Rodríguez, ${ }^{*}$ A. Arís, ${ }^{*}$ and A. Bach ${ }^{*}{ }^{1}$ \\ *Department of Ruminant Production, Institut de Recerca i Tecnologia Agroalimentàries, 08140 Caldes de Montbui, Spain \\ †Institució Catalana de Recerca i Estudis Avançats, 08010 Barcelona, Spain
}

\begin{abstract}
Dairy cows suffer blood Ca losses as lactation begins and might be affected by hypocalcemia in its clinical (total serum Ca concentration $<1.50 \mathrm{mM}$ ) or subclinical form (total serum Ca concentration $\leq 2.14 \mathrm{mM}$ ). Several studies have suggested that hypocalcemia is associated with different health problems of the cow but results from different studies are not consistent. The objective of this study was to assess potential associations between subclinical hypocalcemia (SCHC) and displaced abomasum, intramammary infections, metritis, retained placenta, and ketosis. Also, the associations between SCHC and milk yield and reproductive function were evaluated. After discarding cows (32) with clinical hypocalcemia, a total of 764 cows from 6 different commercial farms were enrolled in this study. Blood samples were collected at 24 to $48 \mathrm{~h}$ postcalving and analyzed for total Ca concentration. Odds ratios of the different afflictions potentially associated with SCHC were calculated. Seventy-eight percent of the analyzed cows incurred SCHC. The occurrence of displaced abomasum, ketosis, retained placenta, and metritis was $3.7,5.5,3.4$, and 4.3 times more likely, respectively, in cows that had SCHC than in cows with normocalcemia. Furthermore, the risk of incurring retained placenta or metritis increased in multiparous cows as serum Ca concentrations decreased compared with that in primiparous cows. Normocalcemic cows, independent of parity, were more likely to show their first estrus sooner after calving than SCHC cows, but no correlation was found between SCHC and other reproductive parameters. Different serum Ca concentration cutoffs were identified for several postpartum afflictions $(\leq 1.93, \leq 2.05, \leq 2.05$, and $\leq 2.10 \mathrm{~m} M$ for ketosis, retained placenta, metritis, and displaced abomasum, respectively). In conclusion, SCHC, defined as serum $\mathrm{Ca} \leq 2.14 \mathrm{~m} M$, is a frequent illness affecting the major-
\end{abstract}

Received October 26, 2016.

Accepted May 22, 2017.

${ }^{1}$ Corresponding author: alex.bach@icrea.cat ity of the dairy cows with important repercussions on health. However, if SCHC were to be used to predict postpartum disease, different serum Ca cutoff points are likely to be needed because best predictive cutoff values varied among postpartum ketosis, displaced abomasum, retained placenta, and metritis.

Key words: calcium, postcalving disease, risk

\section{INTRODUCTION}

Dairy cows experience important physiological changes around parturition. Due to the onset of lactation, leading to increased demand for $\mathrm{Ca}$, blood $\mathrm{Ca}$ concentration decreases suddenly in the 2 to $3 \mathrm{~d}$ around calving (Quiroz-Rocha et al., 2009), which can overwhelm the homeostatic mechanisms, resulting in insufficient availability of ionized Ca (Horst et al., 1997). The animal is then affected by hypocalcemia, which can be a clinical disease in about $5 \%$ of the cows (NAHMS, 2002), or a subclinical disease with an incidence of around $50 \%$ in cows with more than 2 lactations (Horst et al., 2003). Despite the fact that the severity of the disease is greater in the clinical cases, subclinical cases are also important because (1) they are far more frequent, (2) they cannot be easily diagnosed, and (3) they may impair the longevity and productivity of the cow (Goff, 2008; Murray et al., 2008).

It is commonly assumed that dairy cows experience subclinical hypocalcemia (SCHC) when total serum $\mathrm{Ca}$ is $<2.0 \mathrm{~m} M(8.0 \mathrm{mg} / \mathrm{dL})$ and clinical hypocalcemia when serum Ca levels are $<1.5 \mathrm{~m} M(6.0 \mathrm{mg} / \mathrm{dL}$; Goff, 2008), but other studies apply different ranges to determine the severity of hypocalcemia. For example, Chapinal et al. (2012) defined that a normocalcemic cow would have serum Ca levels $>2.20 \mathrm{~m} M$, Goff (2008) widened the criterion to a range from 2.12 to $2.50 \mathrm{mM}$, and Martinez et al. (2012) proposed $>2.14 \mathrm{mM}$ as the cutoff value for normocalcemia.

Previous studies with dairy cattle have reported associations between clinical hypocalcemia and periparturient disorders, such as dystocia, retained placenta, ketosis, and displaced abomasum (Curtis et al., 1983) 
Table 1. Descriptive statistics of herds and cows enrolled in the study

\begin{tabular}{lccccc}
\hline & & & & \multicolumn{2}{c}{$\begin{array}{c}\text { Parity distribution } \\
\text { (cows enrolled), }{ }^{1} \%\end{array}$} \\
\cline { 5 - 6 } Herd & $\begin{array}{c}\text { No. of } \\
\text { milking cows }\end{array}$ & $\begin{array}{c}\text { Rolling herd } \\
\text { average, } \mathrm{kg} / \mathrm{d}\end{array}$ & $\begin{array}{c}\text { No. of } \\
\text { cows enrolled }\end{array}$ & PMC & MPC \\
\hline 1 & 260 & 36.3 & 49 & 33.3 & 66.7 \\
2 & 1,820 & 34.2 & 342 & 31.7 & 68.4 \\
3 & 220 & 35.4 & 41 & 32.2 & 67.8 \\
4 & 420 & 37.2 & 156 & 34.8 & 65.2 \\
5 & 840 & 39.3 & 132 & 30.4 & 69.6 \\
\hline
\end{tabular}

${ }^{1} \mathrm{PMC}=$ primiparous cows; $\mathrm{MPC}=$ multiparous cows.

as well as hampered fertility, conception, and pregnancy rates (Maizon et al., 2004; Roche, 2006; Martinez et al., 2012). However, literature reports are somewhat contradictory. For instance, Massey et al. (1993) identified SCHC as a risk factor for development of displaced abomasum but others reported no association between these 2 afflictions (LeBlanc et al., 2005; Chamberlin et al., 2013). Similarly, Martinez et al. (2012) found that pregnancy rate and interval between calving and pregnancy were reduced under SCHC, but Chamberlin et al. (2013) reported no differences in the incidence of uterine diseases, services per conception, or days open when comparing normocalcemic with SCHC cows. Reports about the potential association between milk yield and SCHC are also contradictory (Jawor et al., 2012; Martinez et al., 2012). Because of the inconsistency about the possible health consequences of SCHC and the threshold of blood $\mathrm{Ca}$ concentration that should be used to define SCHC, the objectives of the current study were to investigate potential associations between SCHC and milk yield, reproductive performance, and the most important postpartum afflictions of dairy cattle.

\section{MATERIALS AND METHODS}

\section{Animals}

With the aim of monitoring at least 700 cows, during a period of 2 mo (April and May 2013), all cows calving in 6 herds (Table 1) were enrolled in this study. The target of 700 cows was based on an expected incidence of hypocalcemia of $65 \%$ (Martinez et al., 2012), and the fact that previous reports describe increased odds of $\sim 2.0$ for incurring metritis (which typically occurs at $\sim 30 \%$ ) when experiencing hypocalcemia (Markusfeld, 1987). Herds were located in the northeast and east of Spain (Catalonia, Valencia, and Aragón) and were randomly selected from a pool of 19 herds accessible to our research group and complied with minimum requirements (i.e., milk meters, pedometers for estrus detec- tion, good record keeping, and willingness to take blood samples, test for ketosis, and follow protocols). Each herd was visited at least fortnightly during the course of the study to collect data and ensure all protocols were followed. Herds maintained the cows under typical Southern European production conditions. Cows were kept in free-stalls and fed TMR. Three herds split the dry cows into far-off (between around 220 and $260 \mathrm{~d}$ of gestation) and close-up groups (last 3 wk of gestation) and the other 3 herds had a single dry cow pen. One of the 3 herds (herd 1; Table 1) that split dry cows in 2 groups fed anionic salts during the close-up period.

\section{Blood Sampling, Analysis, Data Collection, and Cow Classification}

Blood was collected by venipuncture of the tail vessels using evacuated tubes without additives between 24 and $48 \mathrm{~h}$ postcalving from all cows that calved during the study course. Serum was recovered after centrifugation at $2,000 \times g$ for $15 \mathrm{~min}$ and stored at $-20^{\circ} \mathrm{C}$ until further analysis. Serum Ca concentration was determined using inductively coupled plasmaoptical emission spectrometry (ICP-OES) using an ICP-OES Perkin-Elmer Optima 4300DV (Perkin Elmer Inc., Waltham, MA) after a $1 / 20$ dilution in an EDTA $0.05 \%$ (wt/vol) and $\mathrm{NH}_{3} 0.5 \%$ (vol/vol) solution. The coefficient of interassay variation of the analyses was as 0.8 to $1.4 \%$.

For each cow, milk yield was recorded daily using electronic milk meters. Also, each cow was sampled within the first 30 DIM by DHIA personnel to determine milk SCC (which were also determined by the DHIA). The occurrence of postpartum disorders (ketosis, displaced abomasum, retained placenta, metritis, and mastitis) was recorded from each herd during the first $30 \mathrm{~d}$ postcalving. These diseases were recorded as either present or absent. Ketosis was diagnosed based upon a color change on a KetoStix urine dipstick (Bayer Corporation, Elkhart, IN) performed by farm personnel, on every Tuesday, in all cows within the first 
$7 \mathrm{~d}$ after calving. Briefly, cows were headlocked and manually stimulated to urinate, then the urine strip was directly wetted with the urine stream, and the results were compared with the corresponding color scale after $\sim 10 \mathrm{~s}$. Cows were considered ketotic when the KetoStix strip turned purple, corresponding to a moderate $(\geq 40 \mathrm{mg} / \mathrm{dL})$ or more severe ketosis. Cows were considered to have displaced abomasum when a veterinarian performed the corresponding surgical intervention. Retained placenta was diagnosed when fetal membranes failed to be completely expelled from the birth canal within $12 \mathrm{~h}$ of parturition. Metritis was defined as a cow with a fever (rectal temperature $>39.5^{\circ} \mathrm{C}$ ) and a discolored, foul-smelling uterine discharge diagnosed by farm personnel. Cows were classified as experiencing IMI when treated with antibiotics against IMI during lactation (all cows were treated with antibiotics at dry-off) or when SCC at the DHIA sampling was $>300 \times 10^{3}$ cells $/ \mathrm{mL}$. Last, reproductive performance was assessed by proportion of cows within the first 60 DIM expressing signs of estrus (determined using pedometers that tracked individual cow activity), and the number of AI per conception.

\section{Calculations and Statistical Analysis}

In an initial approach, cows were considered normocalcemic when blood Ca was $>2.14 \mathrm{~m} M$, and considered to suffer $\mathrm{SCHC}$ when blood Ca was $\leq 2.14 \mathrm{~m} M$ following Martinez et al. (2012). Accumulated milk yield in the first 60 DIM, milk SCC, proportion of cows in estrus within the first $60 \mathrm{DIM}$, and number of AI to conceive were analyzed using a mixed-effects model with $\mathrm{SCHC}$ as a binary variable (normocalcemic or SCHC) and parity (primiparous or multiparous cows) and their 2-way interaction as fixed effects and herd and DIM at sampling (first or second) as random effects using SAS (v. 9.4, SAS Institute Inc., Cary, NC).

To assess the potential association between serum Ca and prevalence of different afflictions, the incidence of each of the diseases evaluated herein was analyzed using a mixed-effects logistic regression model with calcemia as a binary variable (normocalcemic or SCHC), parity also as a binary variable (primiparous or multiparous cows), plus their 2-way interaction as fixed effects, and herd and DIM at sampling (first or second) as random effects using Stata (version 13.1 for MacOS, StataCorp LP, College Station, TX). Furthermore, the same mixed-effects logistic model was run but instead of using a binary variable for calcemia, serum Ca entered the model as a continuous variable with parity as a binary variable (primiparous vs. multiparous cows), and their 2-way interaction as fixed effects, and herd and DIM at sampling (first or second) as random effects using Stata (version 13.1 for MacOS, StataCorp LP). If the interaction between calcemia (as a continuous variable) and parity was significant, detection of the cutoff point where a difference in the outcome variable existed between primiparous and multiparous was determined following Long (2006), briefly because in logistic regression the value of the interaction effect changes depending upon the value of the continuous predictor variable (calcemia). Thus, we first computed the predicted probabilities, differences in predicted probabilities, and the confidence interval of the difference in predicted probabilities while holding the continuous predictor (calcemia) at a fixed value and repeated this procedure for the entire range of possible (observed) calcemia values, and then determined in what range of calcemia the $95 \%$ confidence interval of the difference in predicted probabilities did not contain a zero.

Last, a receiver-operating characteristic (ROC) analysis was performed using JMP (version 13.0 for MacOS, SAS Institute Inc.) to assess the ability of using blood $\mathrm{Ca}$ levels to predict the incidence of the evaluated diseases (displaced abomasum, ketosis, metritis, IMI, and retained placenta) herein. Youden's index (Youden, 1950) was used to select an appropriate cutoff serum Ca concentration (considered to be the point where the difference between sensitivity and specificity was minimized) for each pathology assessed.

\section{RESULTS AND DISCUSSION}

During the 2 mo of study, a total of 796 Holstein cows (representing about $18 \%$ of the total yearly calvings from each herd) were recorded. Thirty-two multiparous cows from 5 herds had clinical hypocalcemia (diagnosed by farm personnel based on body temperature and recumbence) and were treated with intravenous $\mathrm{Ca}$ solutions. These cows were removed from the data set. Overall serum $\mathrm{Ca}$ concentrations from the remaining 764 cows was $2.10 \pm 0.014 \mathrm{mM}$ (mean $\pm \mathrm{SE}$ ). Because there is a good correlation between blood ionized and total Ca concentrations (Blum et al., 1972; Kvart and Larsson, 1978; Kvart et al., 1982), we used the latter to determine the range of blood Ca concentration. All 764 cows remained at their respective herds during the entire duration of the study. From the 764 cows in the study, 611 (78.0\%) experienced SCHC (defined as serum $\mathrm{Ca} \leq 2.14 \mathrm{mM}$ ). To our knowledge, this is one of the greatest figures of $\mathrm{SCHC}$ prevalence reported in the literature, much greater, for example, than the $47 \%$ assigned to multiparous cows by Reinhardt et al. (2011). This might be related to the serum Ca concentrations used as cutoff herein $(2.14 \mathrm{~m} M$ or $8.59 \mathrm{mg} / \mathrm{dL})$, which was greater than the value $(2.00 \mathrm{~m} M)$ used in Reinhardt et al. (2011) to define SCHC. For instance, Martinez et 
al. (2012), using the same cutoff point for SCHC as in the current study reported a $65.5 \%$ incidence of SCHC, and Caixeta et al. (2015) using a cutoff point of 2.00 $\mathrm{m} M$ reported a $60 \%$ incidence for cows with $\geq 3$ lactations using a $2.15 \mathrm{~m} M$ cutoff point to define SCHC. It is important to mention that herd 1 used anionic salts, but the effect of feeding anionic salts on the incidence of SCHC could not be assessed herein due to lack of replication (only 1 herd).

Mean serum Ca concentrations of cows with SCHC was $1.95 \pm 0.01 \mathrm{~m} M$. Normocalcemic cows had a mean serum Ca concentration of $2.25 \pm 0.01 \mathrm{mM}$. Primiparous cows had greater $(P<0.001)$ serum $\mathrm{Ca}$ concentration $(2.21 \pm 0.01 \mathrm{mM})$ than multiparous $(2.08 \pm 0.01 \mathrm{mM})$ cows (Table 2). There was an interaction $(P<0.01)$ for serum Ca between parity and calcemia classification, with SCHC multiparous cows having lower serum Ca concentrations than SCHC primiparous cows (Table 2). Parity of SCHC cows $(2.36 \pm 0.06)$ was greater $(P<$ $0.0001)$ than that of normocalcemic $(1.70 \pm 0.09)$ cows, or in other words, $85 \%$ of multiparous cows and $14.3 \%$ of the primiparous cows were classified as SCHC.

No differences were observed in milk produced during the first 60 DIM between SCHC and normocalcemic cows (Table 2), which disagrees with previous studies (Jawor et al., 2012) reporting that milk production from SCHC cows was greater than in normocalcemic cows. However, there are contradictory reports about the potential association between milk yield and SCHC in the literature, with some studies reporting no correlation (Shappell et al., 1987; Østergaard and Larsen, 2000; Martinez et al., 2012) and others describing greater milk production in SCHC than in normocalcemic cows (Curtis et al., 1984; Jawor et al., 2012). Regarding udder health, the lack of differences in milk SCC between normocalcemic and SCHC cows herein would indicate that the decrease in calcemia under $\mathrm{SCHC}$ was not sufficiently large to compromise immune response as it would occur under clinical hypocalcemia. Several articles have described that the depletion of intracellular Ca stores in peripheral blood mononuclear cells (Kimura et al., 2006) under clinical hypocalcemia may compromise immune response (Hammon et al., 2006; Silvestre et al., 2011) through a decreased neutrophil function (Ducusin et al., 2003; Martinez et al., 2012) and this could affect mastitis incidence or elevate SCC.

Our study confirms that normocalcemic cows were more likely to have their first estrus (detected using pedometers) sooner after calving than SCHC cows. The proportion of normocalcemic cows that were detected in estrus $(83.2 \pm 21.4 \%)$ within the first 60 DIM was greater $(P<0.001)$ than that of SCHC $(59.5 \pm 21.4 \%)$ cows (data not shown), which was probably linked to postpartum uterine problems (discussed later) associated with SCHC, as it has been previously shown that uterine disease has a negative effect on ovarian cyclicity (Sheldon et al., 2002). However, and in agreement with Chamberlin et al. (2013), we found no association between the number of AI needed to reach conception and SCHC (Table 2).

Overall incidence of displaced abomasum, IMI, ketosis, metritis, and retained placenta in the current study was $6.9,20.5,12.6,37.4$, and $12.2 \%$, respectively. Table 3 shows the associations between SCHC, parity, and their interaction with the incidence of several afflictions. No association was found herein between calcemia and incidence of IMI during the first month of lactation. Supporting previous findings (Massey et al., 1993), but in contrast to others (LeBlanc et al., 2005; Chamberlin et al., 2013), in the present study SCHC cows had 3.7 greater $(P<0.01)$ odds of incurring displaced abomasum than normocalcemic cows independent of parity (Table 3). It is possible that with $\mathrm{SCHC}$, the levels of $\mathrm{Ca}$ in blood may be sufficiently low to alter the muscular tone of the abomasum as it occurs in clinical hypocalcemia (Daniel, 1983; Hansen

Table 2. Measured traits of cows classified as normocalcemic or suffering from subclinical hypocalcemia (SCHC)

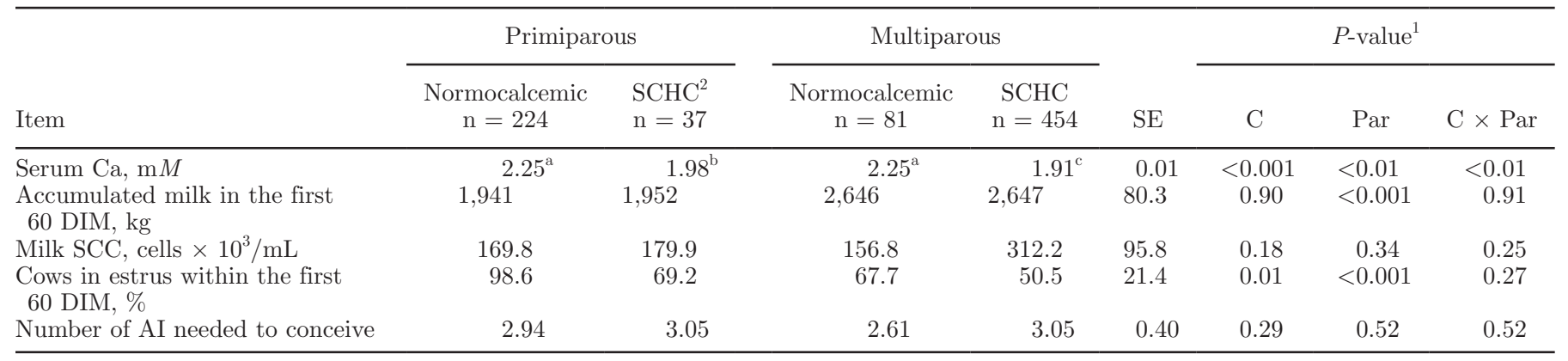

${ }^{\mathrm{a}-\mathrm{c}}$ Values sharing uncommon superscripts differ at $P<0.05$.

${ }^{1} \mathrm{C}=$ effect of serum Ca concentration; Par $=$ effect of parity; $\mathrm{C} \times \mathrm{Par}=$ interaction between calcemia and parity.

${ }^{2}$ Cows were classified as SCHC when serum $\mathrm{Ca} \leq 2.14 \mathrm{mM}$. 
Table 3. Odds ratios of incurring displaced abomasum, IMI, ketosis, metritis, and retained placenta and expressing estrus before 60 DIM as affected by presence of subclinical hypocalcemia (SCHC; absence is the reference point) and parity (primiparous is the reference point)

\begin{tabular}{|c|c|c|c|c|c|c|c|}
\hline \multirow[b]{2}{*}{ Item } & \multicolumn{2}{|c|}{$\mathrm{SCHC}^{1}$} & \multicolumn{2}{|c|}{ Multiparous } & \multicolumn{3}{|c|}{$P$-value ${ }^{2}$} \\
\hline & Odds ratio & $95 \% \mathrm{CI}$ & Odds ratio & $95 \% \mathrm{CI}$ & $\mathrm{C}$ & Par & $\mathrm{C} \times \mathrm{Par}$ \\
\hline IMI & 1.05 & $0.65-1.68$ & 1.82 & $1.14-2.91$ & 0.83 & $<0.01$ & 0.84 \\
\hline Ketosis & 5.47 & $1.80-16.65$ & 1.68 & $0.55-5.12$ & $<0.001$ & 0.36 & 0.06 \\
\hline Metritis & 4.25 & $2.62-6.89$ & 1.72 & $1.05-2.78$ & $<0.01$ & $<0.01$ & 0.02 \\
\hline Retained placenta & 3.43 & $0.50-2.11$ & 1.03 & $0.50-2.11$ & $<0.001$ & 0.05 & 0.03 \\
\hline
\end{tabular}

et al., 2003). Cows classified as SCHC had 5.5 greater $(P<0.01)$ odds of having ketosis than normocalcemic cows, independent of parity (Table 3 ). This observation is agreement with Curtis et al. (1983). The increased risk of ketosis could not be attributed to differences in milk yield between normocalcemic and SCHC cows as milk production did not differ, thus the increased risk of ketosis observed herein and in other studies may be caused by mechanisms different than changes in milk production per se and are probably linked to alterations in glucose metabolism. For instance, Schlumbohm and Harmeyer (1990) reported that hypocalcemia induces a reduction of glucose utilization in pigs, which seems to be mediated by a decreased insulin secretion under low calcemia (Witzel and Littledike, 1973); however, whether this mechanism could be involved in ruminants is unknown.

Regarding uterine health, subclinical hypocalcemia has been previously related to metritis and retained placenta (Curtis et al., 1983; Goff and Horst, 1997). Because under SCHC immune function may be impaired and muscle contraction diminished (Murray et al., 2008), metritis and retained placenta are more prone to occur (Martinez et al., 2012). In the current study, an interaction was present between calcemia and parity for the incidence of retained placenta and metritis (Table 3). As in previous studies, both retained placenta and metritis were more likely (odds ratio $>3.0$; $P<0.01)$ to occur in SCHC than in normocalcemic cows, but multiparous cows with SCHC had $4.85(95 \%$ $\mathrm{CI}=2.93-8.13)$ greater $(P<0.05)$ odds of having metritis compared with normocalcemic multiparous cows. Furthermore, the probability of incurring the disease evolved differently depending on the serum Ca concentrations and parity of the cow. Figure 1 shows the difference in probability of incurring metritis between primiparous and multiparous cows depending on serum Ca levels. Multiparous cows were more likely $(P<0.05)$ to suffer metritis than primiparous cows, when serum Ca levels were $\leq 2.10 \mathrm{~m} M$. Similarly, mul- tiparous cows were more likely $(P<0.05)$ to suffer retained placenta than primiparous cows (Table 3), and multiparous cows that experienced SCHC had 3.57 $(95 \%$ CI $=1.21-10.47)$ greater odds of experiencing retained placenta than normocalcemic multiparous cows. Furthermore, multiparous cows were more likely $(P<0.05)$ to suffer retained placenta than primiparous cows when serum Ca concentrations were $\leq 1.70 \mathrm{mM}$ (Figure 2). The odds of expressing estrus (as detected using pedometers) before 60 DIM were lower $(P<0.01)$ in SCHC cows than in normocalcemic cows (Table 3 ). Martinez et al. (2012) reported that both time to first estrus and pregnancy were delayed in SCHC compared with normocalcemic cows, and more recently, Caixeta et al. (2017) reported that cows with normocalcemia were 1.8 times more likely to return in estrus by the end of the voluntarily waiting period than cows classified as having subclinical hypocalcemia (defined as blood Ca $\leq 2.00 \mathrm{mM}$ ).

Last, the ROC analysis suggested a serum Ca cutoff point of $\leq 1.93 \mathrm{mM}$ as a predictor of ketosis (with a specificity of $58.0 \%$ and a sensitivity of $67.4 \%$ ). For retained placenta, the ROC analysis yielded a serum $\mathrm{Ca}$ cutoff point of $\leq 2.05 \mathrm{~m} M$ (with a specificity of $39.9 \%$ and a sensitivity of $90.7 \%$ ) and for metritis the serum Ca cutoff was $\leq 2.05 \mathrm{~m} M$ (with a specificity of $41.8 \%$ and a sensitivity of $85.3 \%$ ). For displaced abomasum, the serum Ca concentration cutoff was $\leq 2.10 \mathrm{~m} M$ (with a specificity of $54.9 \%$ and a sensitivity of $62.9 \%$ ). For the risk of IMI no significant serum Ca cutoff point could be identified $(P=0.24)$, which could either be due to the low prevalence of IMI herein or just a lack of effect on udder health, or due to the method to classify IMI herein (based on either clinical observation or SCC $>300 \times 10^{3}$ cells $/ \mathrm{mL}$ ). Thus, establishing a single cutoff point for determining SCHC based on the posterior consequences on health does not seem possible; however, it seems that a cutoff of $2.05 \mathrm{~m} M$ may be more specific than the $2.14 \mathrm{~m} M$ proposed by Martinez et al. (2012) and used herein. Nevertheless, accurate prediction of 


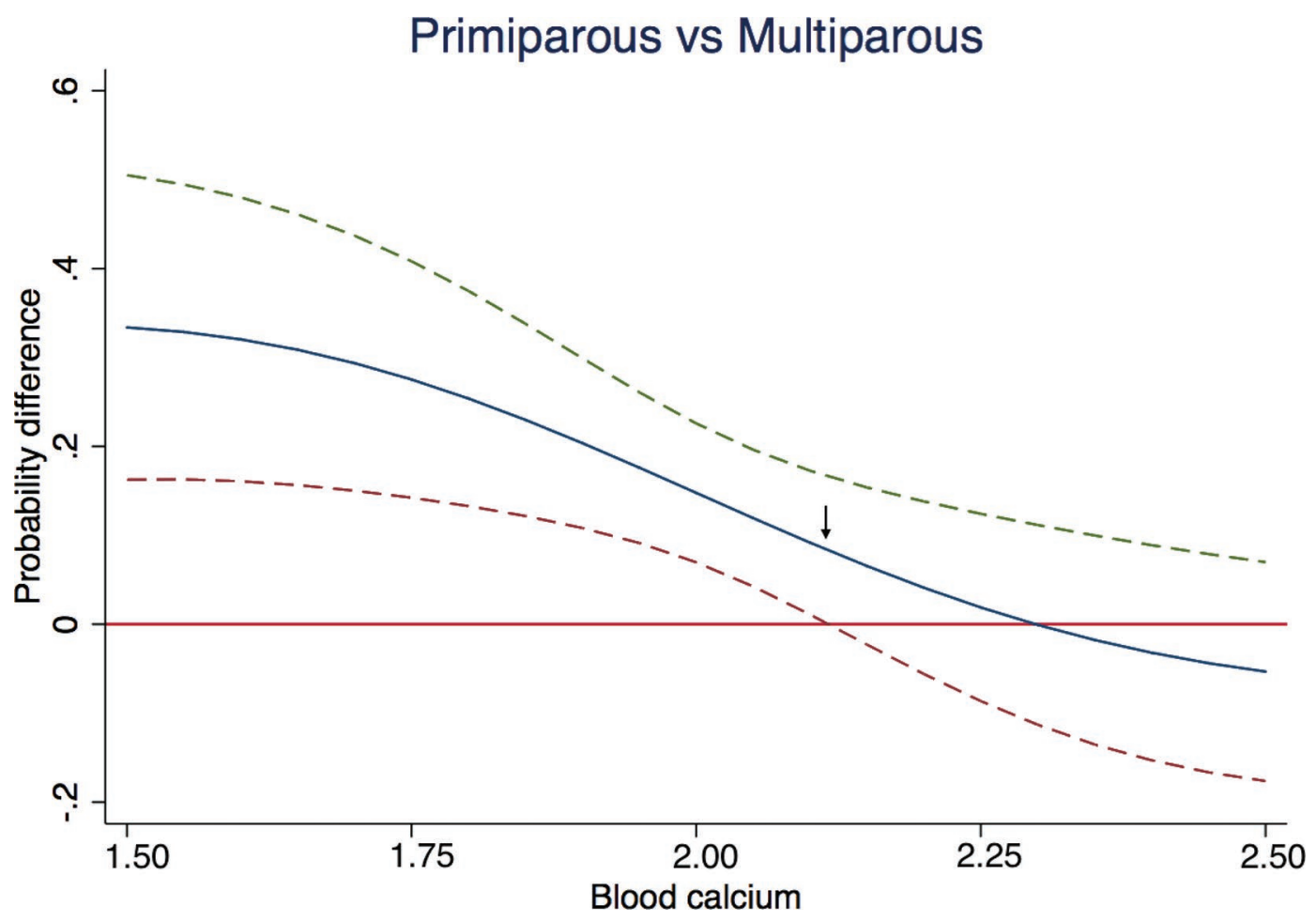

Figure 1. Probability difference (solid line) of incurring metritis between primiparous and multiparous cows as affected by blood Ca levels $(\mathrm{m} M)$. Dashed lines represent upper and lower probability difference bounds. The arrow depicts the blood Ca concentration below which probability starts to differ. Color version available online.

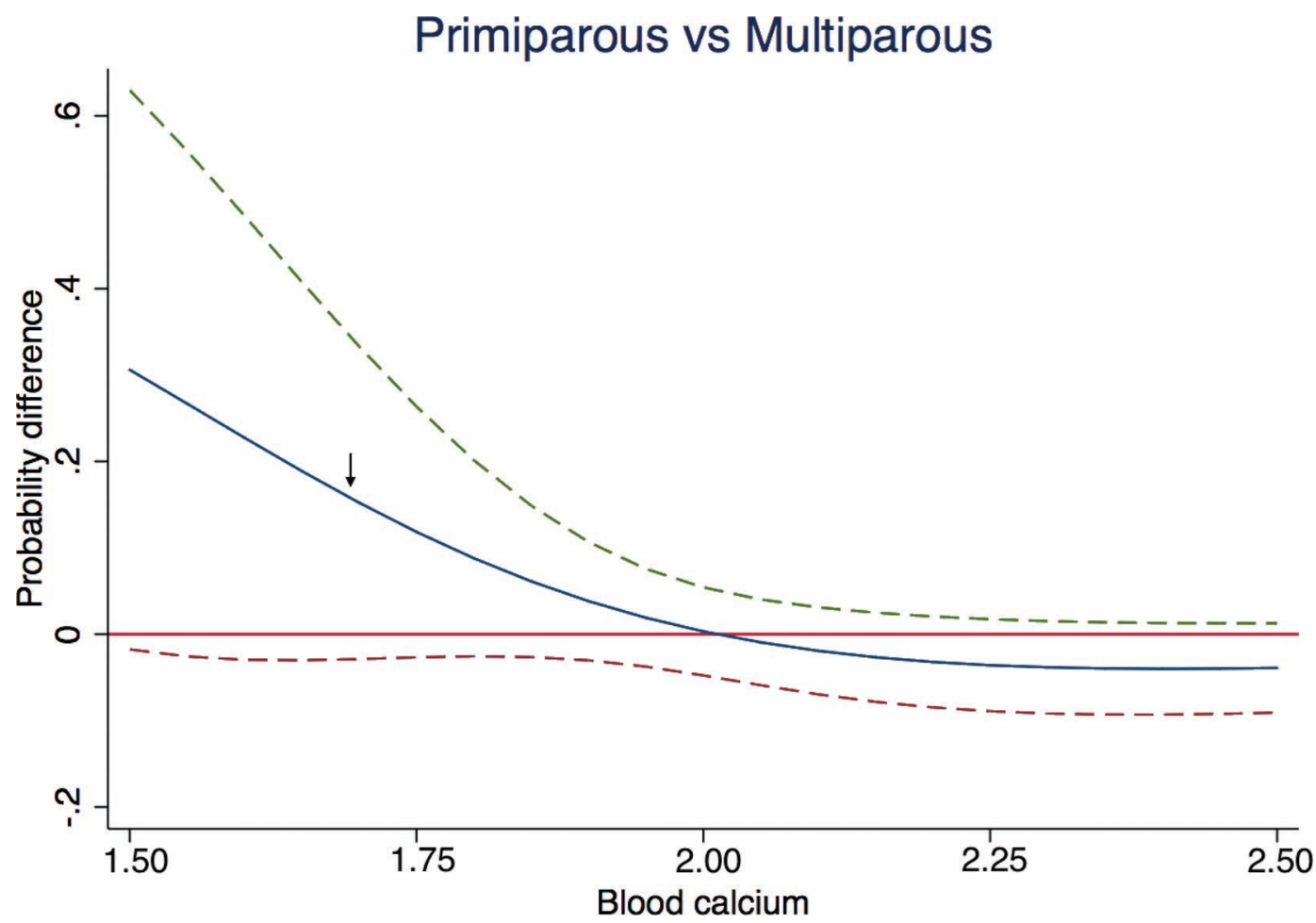

Figure 2. Probability difference of incurring retained placenta between primiparous and multiparous cows as affected by blood Ca levels $(\mathrm{m} M)$. Dashed lines represent upper and lower probability difference bounds. The arrow depicts the blood Ca concentration below which probability starts to differ. Color version available online. 
postpartum disease based on calcemia within the first $48 \mathrm{~h}$ after calving may require the use of different cutoff points. Furthermore, the consequences of calcemia (and the cutoff point to use) on uterine health may differ between primiparous and multiparous cows.

\section{CONCLUSIONS}

Subclinical hypocalcemia is an important periparturient affliction with a high incidence and bold consequences in the postpartum health of cows. Subclinical hypocalcemia is associated with an increased risk of incurring ketosis, displaced abomasum, metritis, and retained placenta, with the last 2 afflictions being more likely in multiparous than in primiparous cows as the severity of hypocalcemia increases. Subclinical hypocalcemia also delays the first estrus after calving and reduces the odds of cows expressing estrus signs during the first $60 \mathrm{~d}$ of lactation. Serum Ca concentrations as high as $2.14 \mathrm{~m} M$ are already associated with increased risk of postpartum diseases, but because the risk of incurring postcalving afflictions varies depending on the severity of subclinical hypocalcemia, different serum Ca cutoff points may be necessary to assess the effect on different postpartum diseases.

\section{ACKNOWLEDGMENTS}

We thank the Instituto Nacional de Investigación y Tecnología Agraria y Alimentarias (INIA, Madrid, Spain) for the partial financial support of this project (RTA2009-00051-00-00) and a doctoral fellowship. We also thank the Servei de Química Analítica at the Autonomous University of Barcelona for their technical assistance. Last, the Centres de Recerca de Catalunya program (Barcelona, Spain) from Generalitat de Catalunya is acknowledged for supporting this research.

\section{REFERENCES}

Blum, J. W., C. F. Ramberg, K. G. Johnson Jr., and D. S. Kronfeld. 1972. Calcium (ionized and total), magnesium, phosphorus, and glucose in plasma from parturient cows. Am. J. Vet. Res. 33:51-56.

Caixeta, L. S., P. A. Ospina, M. B. Capel, and D. V. Nydam. 2015. The association of subclinical hypocalcemia, negative energy balance and disease with bodyweight change during the first 30 days post-partum in dairy cows milked with automatic milking systems. Vet. J. 204:150-156.

Caixeta, L. S., P. A. Ospina, M. B. Capel, and D. V. Nydam. 2017. Association between subclinical hypocalcemia in the first 3 days of lactation and reproductive performance of dairy cows. Theriogenology 94:1-7.

Chamberlin, W. G., J. R. Middleton, J. N. Spain, G. C. Johnson, M. R. Ellersieck, and P. Pithua. 2013. Subclinical hypocalcemia, plasma biochemical parameters, lipid metabolism, postpartum disease, and fertility in postparturient dairy cows. J. Dairy Sci. 96:7001-7013.
Chapinal, N., M. E. Carson, S. J. LeBlanc, K. E. Leslie, S. Godden, M. Capel, J. E. P. Santos, M. W. Overton, and T. F. Duffield. 2012. The association of serum metabolites in the transition period with milk production and early-lactation reproductive performance. J. Dairy Sci. 95:1301-1309.

Curtis, C. R., H. N. Erb, C. J. Sniffen, and R. D. Smith. 1984. Epidemiology of parturient paresis: predisposing factors with emphasis on dry cow feeding and management. J. Dairy Sci. 67:817-825.

Curtis, C. R., H. N. Erb, C. J. Sniffen, R. D. Smith, P. A. Powers, M. C. Smith, M. E. White, R. B. Hillman, and E. J. Pearson. 1983. Association of parturient hypocalcemia with eight periparturient disorders in Holstein cows. J. Am. Vet. Med. Assoc. 183:559-561.

Daniel, R. C. W. 1983. Motility of the rumen and abomasum during hypocalcemia. Can. J. Comp. Med. 47:276-280.

Ducusin, R. J., Y. Uzuka, E. Satoh, M. Otani, M. Nishimura, S. Tanabe, and T. Sarashina. 2003. Effects of extracellular $\mathrm{Ca}^{2+}$ on phagocytosis and intracellular $\mathrm{Ca}^{2+}$ concentrations in polymorphonuclear leukocytes of postpartum dairy cows. Res. Vet. Sci. $75: 27-32$.

Goff, J. P. 2008. The monitoring, prevention, and treatment of milk fever and subclinical hypocalcemia in dairy cows. Vet. J. 176:50-57.

Goff, J. P., and R. L. Horst. 1997. Physiological changes at parturition and their relationship to metabolic disorders. J. Dairy Sci. 80:1260-1268.

Hammon, D. S., I. M. Evjen, T. R. Dhiman, J. P. Goff, and J. L. Walters. 2006. Neutrophil function and energy status in Holstein cows with uterine health disorders. Vet. Immunol. Immunopathol. 113:21-29.

Hansen, S. S., P. Nørgaard, C. Pedersen, R. J. Jørgensen, L. S. Mellau, and J. D. Enemark. 2003. The effect of subclinical hypocalcaemia induced by Na2EDTA on the feed intake and chewing activity of dairy cows. Vet. Res. Commun. 27:193-205.

Horst, R. L., J. P. Goff, and T. A. Reinhardt. 2003. Role of vitamin D in calcium homeostasis and its use in prevention of bovine periparturient paresis. Acta Vet. Scand. Suppl. 97:35-50.

Horst, R. L., J. P. Goff, T. A. Reinhardt, and D. R. Buxton. 1997. Strategies for preventing milk fever in dairy cattle. J. Dairy Sci. 80:1269-1280.

Jawor, P. E., J. M. Huzzey, S. J. LeBlanc, and M. A. G. von Keyserlingk. 2012. Associations of subclinical hypocalcemia at calving with milk yield, and feeding, drinking, and standing behaviors around parturition in Holstein cows. J. Dairy Sci. 95:1240-1248.

Kimura, K., T. A. Reinhardt, and J. P. Goff. 2006. Parturition and hypocalcemia blunts calcium signals in immune cells of dairy cattle. J. Dairy Sci. 89:2588-2595.

Kvart, C., K. A. Björsell, and L. Larsson. 1982. Parturient paresis in the cow. Serum ionized calcium concentrations before and after treatment with different calcium solutions-classification of different degrees of hypo- and hypercalcemia. Acta Vet. Scand. 23:184-196.

Kvart, C., and L. Larsson. 1978. Studies on ionized calcium in serum and plasma from normal cows. Its relation to total serum calcium and the effects of sample storing. Acta Vet. Scand. 19:487-496.

LeBlanc, S. J., K. E. Leslie, and T. F. Duffield. 2005. Metabolic predictors of displaced abomasum in dairy cattle. J. Dairy Sci. $88: 159-170$.

Long, J. S. 2006. Group comparisons and other issues in interpreting models for categorical outcomes using Stata. Presentation at 5th North American Users Group Meeting, Boston, MA.

Maizon, D. O., P. A. Oltenacu, Y. T. Gröhn, R. L. Strawderman, and U. Emanuelson. 2004. Effects of diseases on reproductive performance in Swedish Red and White dairy cattle. Prev. Vet. Med. $66: 113-126$.

Markusfeld, O. 1987. Periparturient traits in seven high dairy herds. incidence rates, association with parity, and interrelationships among traits. J. Dairy Sci. 70:158-166.

Martinez, N., C. A. Risco, F. S. Lima, R. S. Bisinotto, L. F. Greco, E. S. Ribeiro, F. Maunsell, K. Galvão, and J. E. P. Santos. 2012. Evaluation of peripartal calcium status, energetic profile, and neutrophil function in dairy cows at low or high risk of developing uterine disease. J. Dairy Sci. 95:7158-7172. 
Massey, C. D., C. Wang, G. A. Donovan, and D. K. Beede. 1993. Hypocalcemia at parturition as a risk factor for left displacement of the abomasums in dairy cows. J. Am. Vet. Med. Assoc. 203:852-853.

Murray, R. D., J. E. Horsfield, W. D. McCormick, H. J. Williams, and D. Ward. 2008. Historical and current perspectives on the treatment, control and pathogenesis of milk fever in dairy cattle. Vet. Rec. 163:561-565.

NAHMS (National Animal Health Monitoring Service). 2002. Dairy 2002. Part I: Reference of dairy health and management in the United States. USDA-APHIS-VS. Accessed Oct. 12, 2016. https:// www.aphis.usda.gov/animal_health/nahms/dairy/downloads/ dairy02/Dairy02_dr_PartI.pdf.

Østergaard, S., and T. Larsen. 2000. Associations between blood calcium status at calving and milk yield in dairy cows. J. Dairy Sci. 83:2438-2440.

Quiroz-Rocha, G. F., S. J. LeBlanc, T. F. Duffield, D. Wood, K. E. Leslie, and R. M. Jacobs. 2009. Reference limits for biochemical and hematological analytes of dairy cows one week before and one week after parturition. Can. Vet. J. 50:383-388.

Reinhardt, T. A., J. D. Lippolis, B. J. McCluskey, J. P. Goff, and R. L. Horst. 2011. Prevalence of subclinical hypocalcemia in dairy herds. Vet. J. 188:122-124.
Roche, J. F. 2006. The effect of nutritional management of the dairy cow on reproductive efficiency. Anim. Reprod. Sci. 96:282-296.

Schlumbohm, C., and J. Harmeyer. 1990. Hypocalcemia reduces rate of disappearance of glucose from plasma. Zentralbl. Veterinarmed. A 37:285-293.

Shappell, N. W., J. H. Herbein, L. J. Deftos, and R. J. Aiello. 1987. Effects of dietary calcium and age on parathyroid hormone, calcitonin and serum and milk minerals in the periparturient dairy cow. J. Nutr. 117:201-207.

Sheldon, I. M., D. E. Noakes, A. N. Rycroft, D. U. Pfeiffer, and H. Dobson. 2002. Influence of uterine bacterial contamination after parturition on ovarian dominant follicle selection and follicle growth and function in cattle. Reproduction 123:837-845.

Silvestre, F. T., T. S. M. Carvalho, P. C. Crawford, J. E. P. Santos, C. R. Staples, T. Jenkins, and W. W. Thatcher. 2011. Effects of differential supplementation of fatty acids during the peripartum and breeding periods of Holstein cows: II. Neutrophil fatty acids and function, and acute phase proteins. J. Dairy Sci. 94:2285-2301.

Witzel, D. A., and E. T. Littledike. 1973. Suppression of insulin secretion during induced hypocalcemia. Endocrinology 93:761-766.

Youden, W. J. 1950. Index for rating diagnostic tests. Cancer 3:32-35. 